\title{
DEVELOPMENT OF THE CREATIVITY IN TECHNICAL EDUCATION
}

\section{Jan NOVOTNÝ}

\begin{abstract}
Basic education is intended to provide general education that is unique and decisive for further development of the life of every individual. In this general education must have its place even technical education, which has along with other natural science subjects to give students a basic quantum of technical knowledge and skills, develop technical thinking, creativity, helping to develop their key competencies. The creative process is undergoing human society since its inception. With the improvement of the basic means of technical teaching increases the possibility of further work. Nowadays a broad concept of creativity is based on the assumption that each person can create and creativity can occur in each activity, and therefore in each lesson of basic school.

The research, which is described in the article, is focused on the creative abilities of students on basic schools. It is a transversal research of creative abilities of second grade elementary school students. Research study was also targeted to academic groups with which students can get into close contact. The aim of the described research was to map the level of technical imagination (creativity) by means of shape-folding test, measurement the practical intelligence test, and level of creative thinking using Torrance figural test of creative thinking.
\end{abstract}

Key words: Creativity, research, abilities, technical education article, mistakes, template.

\section{ROZVOJ TVOŘIVOSTI V TECHNICKÉM VZDĚLÁVÁNÍ}

Resumé: Základní vzdělávání má za cíl poskytnout všeobecný základ, který je jedinečný a rozhodující pro další rozvoj života každého individuálního jedince. V tomto všeobecném vzdělávání musí mít své nezastupitelné místo i technické vzdělávání, které má spolu s dalšími přírodovědnými obory i stěžejní úlohu, kdy studenti a žáci získali základní kvantum technických znalostí a dovedností. Tento druh vzdělání rozvíjí technické myšlení, technickou tvořivost a pomáhá rozvíjet žákovské klíčové kompetence.

Tvưrčí proces prochází lidskou společnost od jejího vzniku. V současné době je tvořivost široký pojem, který vychází z předpokladu, že každý člověk může vytvořit a může být tvořivý. Tvořivost jej provází při každé činnosti, a také $\mathrm{v}$ průběhu výuky technických předmětů. Výzkum, který je popsán $\mathrm{v}$ tomto článku, je zaměřen na tvưrčí schopnosti žáků na základních školách. Jedná se o transversální výzkum tvořivých schopností žáků druhého stupně základních škol. Výzkumná studie byla rovněž zaměřena na skupiny akademických pracovníkủ, s nimiž se studenti a žáci budou v průběhu studia dostávat do úzkého kontaktu. Cílem popsaného výzkumu bylo zmapovat úroveň technické představivosti (tvořivosti) pomocí tvarového skládacího testu v porovnání $\mathrm{s}$ měřením praktické inteligence, a úrovně kreativního myšlení pomocí Torranceho figurálního testu tvořivého myšlení.

Klíčová slova: Kreativita, výzkum tvořivých schopností, technické vzdělání

\section{Research objectives}

By student's appropriate motivation and mobilization by adequately methods is possible to increase the efficiency of the teaching process in the field of technical education. Such methods can achieve significantly better work, greater autonomy in decision making and management of work. Finally, in this way can significantly affect student creativity.

The research part is focused on research of creative abilities of pupils in technical education in practical activities in second grade of primary school. The main research areas are the facts leading to answer to main research questions:

- Can respondents, whom obtain good results in non-verbal creativity comparable results in technical creativity test?

- Is increasing level of non-verbal creativity during the second grade of basic school study?

- Is increasing level of technical creativity during the second grade of basic school study? 
- Will teachers achieving good scores in tests of creativity good results in tests of technical creativity?

In accordance with the objective of the research were established the basic research questions:

I. Is there a relationship of respondents between the results of the figural Torrance test of creative thinking and the results achieved in the shapefolding test of technical creativity?

II. Has respondent's age factor any influence to the final score of Torrance test?

III. Has respondent's age factor any influence to the final score of shape-folding test of technical creativity?

IV. Are there significant differences in the results of academic groups achieved in both tests?

Why respondents who achieve relatively high scores on tests of creative thinking, do not have such a high value on technical creativity tests? One reason may be activity of the brain, specifically the activities of its right and left halves. Research has shown that a large brain controls all memory and learning skills. The tasks between the right and left half of the brain, the right half of the brain tasks rhythm, spatial awareness, imagination, daydreaming, colours... The left half of the brain, by contrast, deals with words, logic, numbers, sequences, summaries and analysis. And it may be the cause of the results of our tests of creative ability. If people are undergoing training depending on the activities of more than one half of the brain on the other, gradually creating a dominant habits and than in later life they prefer controlling the activities of same brain hemisphere. But a combination of both can achieve surprising results.

\section{Research tools and research methods}

For the data obtaining were used standardized creativity tests:

- Shape folding test to determine the level of technical imagination (creativity).

- Torrance Figural test of creative thinking to determine the level of creative thinking.

- Statistical methods for verification of specified hypotheses.

- Monitoring of research papers.

\subsection{Shape folding test}

To determine the level of technical creativity of pupils was chose Shape folding test. Its author is G. A. Lienert. In the first stage was chosen form of A. To verify the changes after experimental exposure to students in the third stage of tests was used form B. This ensures that no distortion of the experiment due to the fact that the students remember the correct answers to quiz questions.

Test Characteristics:

Shape folding test especially trying, as long ago called "practical intelligence", ie ability to successfully address the new tasks of practical nature.

\subsection{Torrance figural test of creative thinking}

Author himself considers these tests as those that are finding creative thinking skills. That means constellation of generalized mental abilities, which are commonly assumed that apply to creative performance.

\section{Development of creativity on second grade of basic school}

Respondents from the $6^{\text {th }}$ school year of basic school reach in the Technical creativity test to drop (only above-average results, but these same respondents reach the second high degree of above-average overall performance in the Torrance test. It is a clear example of the independence of the results of both tests. It is impossible to predict each other test.

Another drop in the results of the TST record at $8^{\text {th }}$ school year, when it was recorded the largest percentage of below-average values of the test set. $8^{\text {th }}$ school year pupils have the greatest frequency of below-average results from both tests throughout the test file. The best result in the second grade of primary school in the Technical creativity test reached pupils of $7^{\text {th }}$ and $9^{\text {th }}$ classes while they were almost like a little less successful in Torrance test.

Also on the second degree results of the test of technical creativity showed that the technical creativity as an ability or competence is flat in the tested population disproportionately represented. $6^{\text {th }}$ and $8^{\text {th }}$ school year respondents achieve very often extreme results, below average and aboveaverage and only a small percentage of them are in the diameter zone.

On the contrary, equally level of technical creativity and creative thinking was at the same time spread in the population of $7^{\text {th }}$ and $9^{\text {th }}$ school year respondents.

\section{Development of creativity of University students}

First grade primary school's teachers have achieved in $50 \%$ of the average values in the 
Technical creativity test, the highest frequency band around the diameter of respondents sample. $1^{\text {st }}$ grade teachers reached to $61.4 \%$ in aboveaverage test scores in Torrance test of creative thinking. Respondents sample have the lowest frequency of below-average results in both tests. To characterize this sample group, the level of technical creativity surprisingly achieved according to the mean worst, but especially teachers reach average values, the occurrence is very frequent, richly represented in the group. At the same time the same respondents are much more better at Torrance test of creative thinking. Only $1 / 4$ of persons from this group show the results of both tests below average.

The most balanced results in both tests reached the group of Free-time educators. This group reached first position in Torrance test of creative thinking. It is interesting that results of the Technical creativity test are rather average to below average range, but in the Torrance test of creative thinking is this sample group significantly above average.

Sample group of free-time pedagogy students is in the results of both tests similar than group of teachers from the $1^{\text {st }}$ grade of primary schools.

A group of students of technical education teaching is in test's results not similar like other university students groups! Respondents in this group achieved a higher frequency of aboveaverage results in the Technical creativity test. At the same time achieve the highest frequency of below-average results in the Torrance test of creative thinking.

The total score values of achieved results in both tests are evident from the graphs in Figures 1 and 2 .

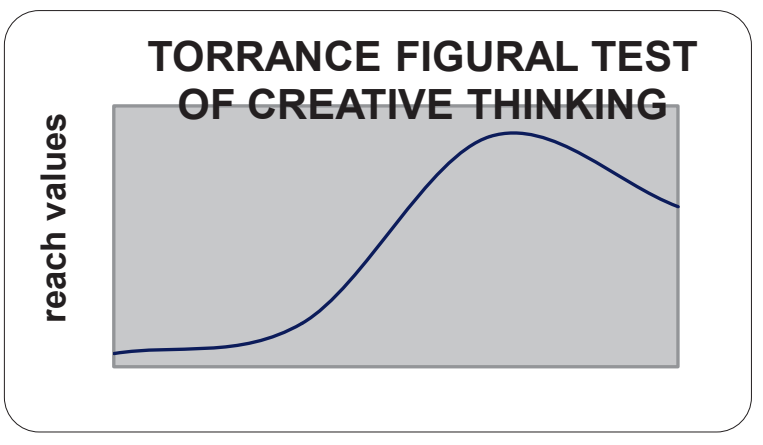

Fig. 1. Sample group's results of the Torrance test of creative thinking

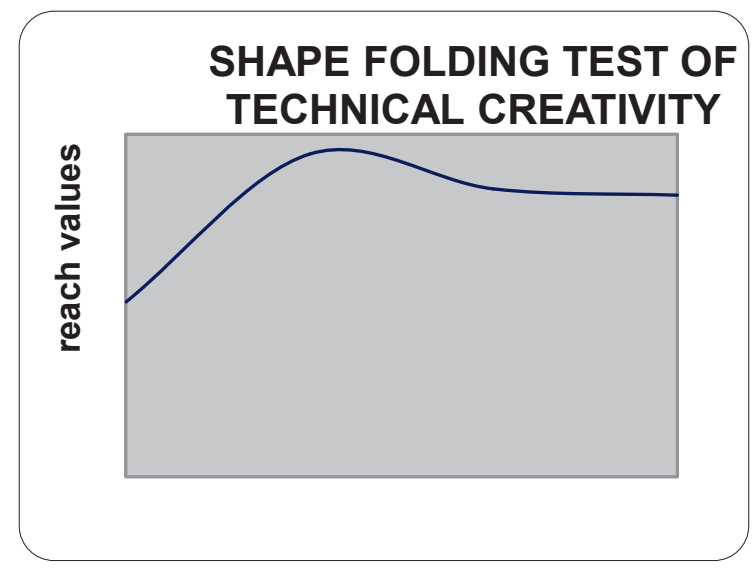

Fig. 2. Sample group's results of the Technical creativity test

\section{Results of research findings}

There are significant differences between the results obtained in the Torrance test of creative thinking and results achieved in the Test of technical creativity for all respondents.

Research confirmed the independence of the results between respondents of both tests.

The relationship between age and the resulting score's factor of Figural Torrance test of creative thinking could not be tested, without exception. There is evident increasing of creative thinking level with respondent's age.

The relationship between age and the resulting score's factor of the Shape folding test of technical creativity could not be tested, without exception. There is evident that with increasing respondent's age does not increase the score of technical creativity test. The score of technical creativity test increases for $2^{\text {nd }}$ grade of primary school scholars.

\section{References}

[1] BUZAN, T. 2007. Mentální mapování. Praha : Portál, 2007. ISBN 978-80-7367-200-3. [2] CHRÁSKA, M. Didaktické testy v práci učitele, 1998. Olomouc: KPÚ.

[3] HONZÍKOVÁ, J. Teorie a praxe tvořivosti v pracovní výchově. Plzeň, Pedagogické centrum, 2003. 239 s. ISBN 80-7020-124-X.

[4] HONZÍKOVÁ, J.; MACH, P.; NOVOTNÝ, J. Alternative Approaches to Technical Education. Plzeň: ZČU, 2007.

[5] HLAVSA, J. 1981. Psychologické problémy výchovy k tvořivosti. Praha : SPN, 1981.

[6] HUTCHINSON, T. Introduction to Project Work, 1991. Oxford: Oxford University 
[7] JURČOVÁ,M. 1984. Torranceho figurálny test tvorivého myslenia. Príručka. Bratislava : Psychodiagnostické a didaktické testy, n.p., 1984.

[8] LOKŠOVÁ, I., LOKŠA, J. 2001. Teória a prax tvorivého vyučovania. Prešov : ManaCon, 2001. ISBN 80-89040-04

[9] ŠVECOVÁ, M., PUMPR, V., BENEŠ, P., HERINK, J. Školní projekt jako kreativní forma výuky př́rodovědných předmětů na základní a střední škole. Pedagogika, 4/2003. Praha: UK. [10] ZELINA, M. Aktivizácia a motivácia žiakov na vyučovaní, 1989. Bratislava: Krajský pedagogický ústav v Bratislavě.
[11] ZUKERSTEIN, J. Aktivizační metody a jejich význam. In Modernizace výuky $\mathrm{v}$ technicky orientovaných oborech a předmětech. Olomouc, UP 1999, s. 135-137.

PhDr. Jan Novotný, Ph.D.

Faculty of Production Technology and Management J. E. Purkyně University in Ústí nad Labem

Na Okraji 1001

Ústí nad Labem

Czech Republic

Tel: +420475285 511

E-mail: novotny@fvtm.ujep.cz 